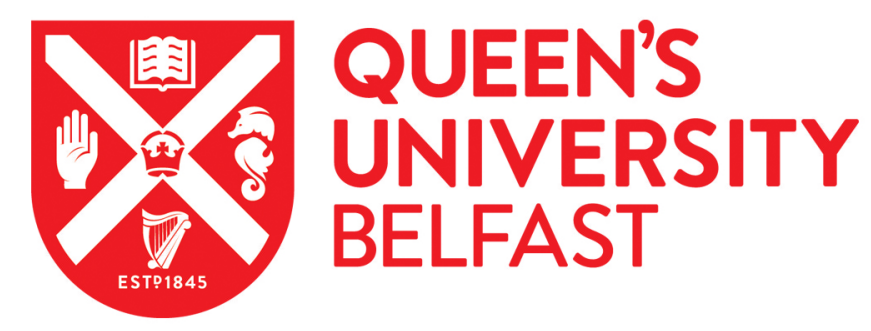

\title{
Clinical Evaluation of Streptococcus pneumoniae Polymerase Chain Reaction in Children with Suspected Septicemia
}

\author{
Bourke, T. W., Fairley, D. J., McKenna, J. P., Coyle, P. V., \& Shields, M. D. (2015). Clinical Evaluation of \\ Streptococcus pneumoniae Polymerase Chain Reaction in Children with Suspected Septicemia. The Pediatric \\ Infectious Disease Journal, 34(11), 1276-7. https://doi.org/10.1097/INF.0000000000000877
}

\section{Published in:}

The Pediatric Infectious Disease Journal

\section{Document Version:}

Peer reviewed version

Queen's University Belfast - Research Portal:

Link to publication record in Queen's University Belfast Research Portal

\section{Publisher rights}

Copyright @ 2015 Wolters Kluwer Health, Inc.

This is a non-final version of an article published in final form in Bourke, TW, Fairley, DJ, McKenna, JP, Coyle, PV \& Shields, MD 2015, 'Clinical Evaluation of Streptococcus pneumoniae Polymerase Chain Reaction in Children with Suspected Septicemia' The Pediatric Infectious Disease Journal, vol 34, no. 11, pp. 1276-7

journal citation).

\section{General rights}

Copyright for the publications made accessible via the Queen's University Belfast Research Portal is retained by the author(s) and / or other copyright owners and it is a condition of accessing these publications that users recognise and abide by the legal requirements associated with these rights.

\section{Take down policy}

The Research Portal is Queen's institutional repository that provides access to Queen's research output. Every effort has been made to ensure that content in the Research Portal does not infringe any person's rights, or applicable UK laws. If you discover content in the Research Portal that you believe breaches copyright or violates any law, please contact openaccess@qub.ac.uk. 


\section{The Pediatric Infectious Disease Journal \\ Clinical evaluation of Streptococcus pneumoniae PCR in children with suspected septicaemia \\ --Manuscript Draft--}

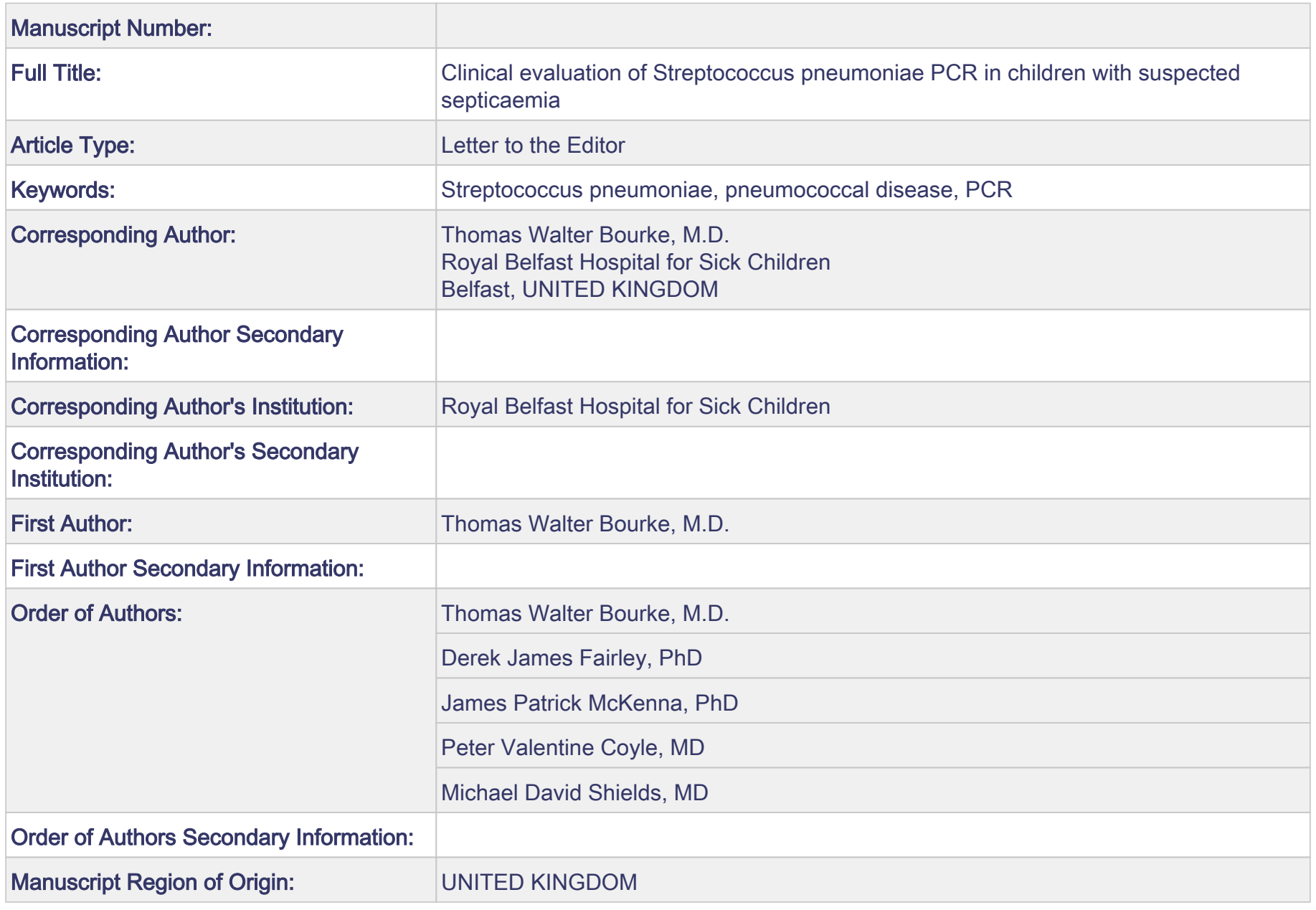




\section{Clinical evaluation of Streptococcus pneumoniae PCR in children with suspected septicaemia.}

Thomas Walter Bourke MD a,c

Derek James. Fairley PhD a,b

James Patrick McKenna PhD ${ }^{b}$

Prof Peter Valentine Coyle MD ${ }^{b}$

Prof Michael David Shields MD ${ }^{a, c}$

${ }^{a}$ Centre for Infection and Immunity, Queen's University Belfast, Belfast, UK

${ }^{\mathrm{b}}$ Regional Virus Laboratory, Department of Microbiology, Belfast Health \& Social Care Trust, Belfast, UK

c Royal Belfast Hospital for Sick Children, Belfast Health \& Social Care Trust, Belfast, UK

Address correspondence to:

Dr Thomas Walter Bourke

Royal Belfast Hospital for Sick Children, Falls Road, Belfast, United Kingdom. BT12 6BE. Telephone 00442890634094 . Fax 00442890632816.

tombourke@doctors.net.uk

Key words:

Streptococcus pneumonia, pneumococcus, PCR 


\section{Abbreviated title}

Pneumococcal PCR in children with suspected sepsis.

Running Title

Pneumococcal PCR in suspected sepsis.

Funding

This research was funded by a fellowship grant to TWB from Health \& Social Care Research and Development Office, Public Health Agency, Northern Ireland. 
Manuscript

Invasive infection with Streptococcus pneumoniae is the second commonest cause of meningitis and septicaemia in childhood, resulting in 10 to $15 \%$ of cases in the UK ${ }^{1,2}$. Isolation of Streptococcus pneumoniae from a normally sterile site remains the gold standard for diagnosis. Blood culture sensitivity is low (around 45\%) and decreases further when antibiotics have been administered (around 20\%) ${ }^{3}$. Despite its accuracy and potential to detect pneumococcus in culture negative patients, the use of molecular testing for Streptococcus pneumoniae is not widespread and not yet recommended as part of routine investigations of suspected septicaemia ${ }^{1,2}$.

We retrospectively tested 117 blood specimens for Streptococcus pneumoniae lytA using previously published PCR assays ${ }^{4}$. These specimens were collected from children with suspected meningitis or septicaemia as part of an ethically approved study on the diagnostic accuracy of Neisseria meningitidis Loop Mediated Isothermal Assay ${ }^{5}$.

Four of the 117 children tested had pneumococcal lytA detected by PCR. Only two of these had invasive pneumococcal disease confirmed by blood culture. The two children who were culture negative had clinical signs of septicaemia: A 10 month old boy with fever vomiting and listlessness who required fluid resuscitation and admission to intensive care; A two year old girl with fever, cough, poor feeding, poor perfusion and focal chest signs.

Evaluating lytA PCR as a confirmatory test for pneumococcus is complicated because it appears to perform better than the gold standard traditional culture. The children included in this study were defined as 'those whom the attending clinician suspected as having meningitis or septicaemia'. Review of the clinical details of the children in this study in combination with a positive lytA PCR make it likely that these children had invasive pneumococcal disease which conventional culture methods failed to 
diagnose. Although our study was small and pneumococcal disease was rare these data suggest that addition of lytA PCR to the routine investigations of children presenting with signs of septicaemia and meningitis is likely to greatly improve laboratory diagnosis of this serious infection. This is clinically a very desirable outcome as treatment for invasive pneumococcal disease requires a longer course of treatment than meningococcal disease ${ }^{2}$. We believe that reviewed National Institute for Health and Care Excellence and other guidelines should consider recommending this test to the panel of investigations of children with suspected meningitis or septicaemia.

1. HPA. Guidance for public health management of meningococcal disease in the UK. London. Health Protection Agency Meningococcus and Haemophilus Forum. 2011.

2. NICE. Bacterial meningitis and meningococcal septicaemia. London: National Institute for Health and Clinical Excellence. 2010.

3. Azzari $C$, Moriondo $M$, Indolfi $G$ et al. Realtime $P C R$ is more sensitive than multiplex PCR for diagnosis and serotyping in children with culture negative pneumococcal invasive disease. PLoS ONE. 2010; 5:e9282.

4. McAvin JC, Reilly PA, Roudabush Ret al. Sensitive and specific method for rapid identification of Streptococcus pneumoniae using real-time fluorescence PCR. J Clin Micro. 2001;39:3446-3451.

5. Bourke T, McKenna J, Coyle P, Shields M, Fairley D. Diagnostic accuracy of 'loop mediated isothermal amplification' (LAMP) as a near-patient test for meningococcal disease in children; an observational cohort study. Lancet Infect Dis. 2015;15:552-558. 
